\title{
JASA PENGANGKUT SAMPAH ( SANGKUTS) BERBASIS ANDROID DI KABUPATEN KUDUS
}

\author{
Arsya Yoga Pratama \\ Fakultas Teknik, Program Studi Sistem Informasi \\ Universitas Muria Kudus \\ Email: 201553011@std.umk.ac.id \\ Yusiana Rahma \\ Fakultas Teknik, Program Studi Sistem Informasi \\ Universitas Muria Kudus \\ Email: yusianarahma30@gmail.com \\ Alifah Normassari \\ Fakultas Hukum, Program Studi Ilmu Hukum \\ Universitas Muria Kudus \\ Email: Aliva.normass@gmail.com
}

\begin{abstract}
ABSTRAK
Jurnal berhubungan dengan jasa pengangkutan sampah yang diolah sebagai barang yang bernilai jual. Sistem tersebut sebagai upaya memanfaatkan sampah menjadi barang yang dapat dijual kembali dan memanfaatkan teknologi untuk mepermudah sistem mengangkutan sampah. Hasil dari perancangan ini adalah Sistem Informasi yang menyajikan hasil analisa dan rancangan yang dituangkan dalam diagram UML (Unified Modeling Language) yang terdiri dari Use Case dan Activity Diagram. Didalam jurnal ini akan menyarankan untuk dapat membuat sebuah sistem yang dapat mempermudah masyarakat untuk mengangkut sampah dengan keuntungan penjualan sampah dan pengolahan sampah yang akan diolah sehingga menjadi barang yang mempunyai niai jual. Hasil dari penelitian ini merupakan salah satu solusi yang dapat digunakan di kabupaten Kudus untuk mengurangi jumlah sampah, Sangkuts adalah jasa mengangkutan sampah yang diperoleh dari masyarakat untuk diolah kembali sehingga dapat bermanfaat dan bernilai jual .Keunggulan aplikasi ini sudah menggunakan teknologi GIS (Geographic Information System).
\end{abstract}

Kata kunci: sampah, sangkuts,usaha, jasa, UML, GIS.

\begin{abstract}
This journal is a connection with a service business transport waste that is processed as a valuable item. The system is an effort to use the waste into a salable item and utilizing technology to simplify waste-transporting systems. The results of this design are the Information System that presents the results of analysis and design as outlined in the diagram UML (Unified Modeling Language) consisting of Use Case and Activity Diagram. In this journal, it will be suggested to create a system that can facilitate hauling garbage with profit of garbage sale and waste processing which will be processed so that the goods have niai selling. The results of this research are one solution that can be used in handling problems in Kabupaten Kudus to reduce the amount of waste. Sangkuts is system aplication service business transport waste can be to be processed again so that it can be useful and worth selling. Excellence applications produced on the basis of GIS (Geographic Information System).
\end{abstract}

Keywords: the waste, sangkuts, businss, service ,UML, GIS.

\section{PENDAHULUAN}

Sampah merupakan permasalahan utama di Indonesia, berdasarkan riset Kementerian Lingkungan Hidup dan Kehutanan (KLHK) menilai persoalan sampah sudah meresahkan. Indonesia bahkan masuk dalam peringkat kedua di dunia sebagai penghasil sampah plastik ke Laut setelah Tiongkok [1]. Untuk dapat menyelesaikan masalah sampah di Indonesia kita dapat memulai dari Kota Kudus. Bank sampah adalah usaha dengan cara mengumpulkan sampah dari para pemulung atau ibu rumah tangga itu sendiri. Penyetor biasanya warga disekitar lokasi bank sampah serta mendapat buku tabungan seperti menabung bank. Bank sampah adalah bisnis yang mengandalkan adanya lingkungan sekitar sehingga kelemahan dari 
keberadaan bank sampah adalah jika masyarakat sekitar tidak memiliki ketertarikan untuk menabung sampahnya, keterbatasan fasilitas untuk menjemput sampah ketimbang menunggu datangnya penyetor sampah dan penyetoran sampah yang sudah dipilah ke industri kreatif tanpa diolah sendiri. Ditengah globalisasi saat ini dengan berbagai macam teknologi yang sangat pesat banyak sekali terciptanya alat untuk membantu masyarakat menyelesaikan persoalan dengan mudah. Salah satu teknologi untuk membantu masyarakat dalam menemukan lokasi adalah GPS. GPS (Global Positioning System) adalah sistem untuk menentukan posisi dan navigasi secara global dengan menggunakan satelit. GPS dapat memberikan informasi tentang posisi, kecepatan, dan waktu secara cepat, akurat, murah, dimana saja bumi ini pada setiap saat tanpa tergantung cuaca [2]. Teknologi GPS biasa digunakan untuk menentukan lokasi dengan akurat.

Dengan permasalahan tersebut maka Tim akan membangun sistem untuk menjemput sampah dengan aplikasi berbasis andorid dan terdapat fitur sangkuts apa saja berupa dokumen, paket,dan lain sebagainya. Aplikasi untuk pengolah sampah ini bekerja dengan cara petugas akan mendatangi rumah penyetor yang sudah melakukan pendaftaran pada aplikasi, selanjutnya kami akan membagi sampah ke bagian non organik ataupun organik kamudian ditimbang, terdapat fitur seperti halnya point yang akan menyimpan jumlah uang yang didapat senilai dengan sampah yang sudah disetorkan. Selanjutnya petugas akan membersihkan dan mengolah sampah itu untuk dijadikan industri kreatif. Setelah menjadi barang bernilai jual maka produk akan dipasarkan melalui Website Aplikasi Sangkuts serta melalui Media Sosial.

\section{METODOLOGI PENELITIAN}

Pada aplikasi Sangkuts yaitu jasa pegangkut sampah berbasis android dengan menjadikannya industri kreatif untuk mengurangi jumlah sampah di kabupaten kudus ini menggunakan metode Pendekatan prototype. Penggunaan metode pendekatan prototype karena sistem akan dibangun dengan berdasarkan desain prototype yang sudah dibuat. Pendekatan prototype digunakan untuk mempercepat implementasi beberapa bagian dari sistem selama atau sebelum persyaratan [3]. Desain prototype, dengan cepat dievaluasi pengguna dan hasil evaluasinya digunakan untuk memperbaiki perangkat lunak yang dikembangkan.

Sistem Aplikasi Sangkuts ini melakukan metode pengembangan sistem yang digunakan yaitu UML. UML adalah alat untuk merinci sistem perangkat lunak yang mencakup diagram standar untuk mendefinisikan, menggambarkan secara visual memetakan atau memodelkan desain dan struktur sistem perangkat lunak [4]. Langkah dalam pembuatan aplikasi Sangkuts yaitu jasa pegangkut sampah berbasis android dengan menjadikannya industri kreatif untuk mengurangi jumlah sampah di kabupaten kudus. Ada 4 tahap yang dilakukan. Pertama ialah Pengumpulan data. Kedua Identifikasi kebutuhan system, Ketiga Desain pelaksanaan sistem, dan yang keempat Implementasi system. Keempat tahap tersebut menjadi rangkaian untuk dapat membuat suatu system dengan kesesuaian kebutuhan yang diperlukan.

Dalam langkah pengumpulan data ini, pertama-tama melakukan pengamatan atau observasi dengan mengamati proses pengangkutan sampah dan pengolahan sampah dengan mencari referensi teknologi untuk mengetahui cara mengimplementasikan sebuah data dengan memanfaatkan teknologi basis data dan teknologi terbaru dalam smartphone android saat ini untuk membuat aplikasi Sangkuts agar dapat lebih valid dalam menyajikan informasi bagi penggunanya.

Selanjutnya langkah kedua menganalisa solusi atas masalah yang terjadi yaitu masyarakat kesulitan dalam membuang sampah dan mengolah sampah. Adapun sebagai data utama dalam pembuatan Aplikasi Sangkuts yang diperlukan adalah data masyarakat, data pelanggan, data barang daur ulang, data lokasi penjemputan sampah. Dalam langkah desain pelaksanaan penelitian dengan melakukan perancangan desain terhadap sistem. Memiliki beberapa urutan yaitu dengan merancang desain sistem yang akan kita buat, membuat konsep desain system, dan membuat desain sistem yang akan dibuat secara rinci.

Pada langkah implementasi penelitian akan menganaisa prototype sistem serta fitur-fitur dalam aplikasi ini. Adapun prototype dari aplikasi adalah kebutuhan hardware dan software. Kebutuhan Hardware dalam sistem terdiri dari Smartphone Android Asus Zenfone 4 Max, Flashdisk 16 GB, 2 buah mouse. Adapun kebutuhan software dalam sistem adalah Windows 10,Andoid studio versi 2.1.2, Java Development kit (JDK), Android SDK, ADT (Android development tools). Fitur yang ada dalam sistem ini ialah dapat mengangkut dokumen atau kiriman dengan meenggunakan aplikasi sangkuts dengan dan mengimplementasikan GPS untuk menentukan aplikasi penjemputan sampah yang akan diangkut oleh petugas.

\section{HASIL DAN PEMBAHASAN}

Berdasarkan hasil pengamatan terhadap lingkungan sekitar di daerah kabupaten Kudus, diketahui bahwa masih sangat kecil pemahaman dan kesadaran tentang pengolahan sampah. Pembuatan aplikasi Sagkuts ini sebagai penunjang usaha dari pengolahan sampah sehingga system dalam usaha Bank Sampah 
dapat optimal. Bertujuan untuk memanfaatkan sampah menjadi barang yang bernilai jual, seperti sampah organik yang akan dijadikan pupuk atau kompos untuk tanaman, sedangkan non organik dijadikan pernak pernik seperti tas, dompet, tempat tisu.

Secara keseluruhan system dari aplikasi Sangkuts ini mengoptimalisasikan kinerja bank sampah dengan penjemputan melalui smartphone. Dengan begitu dapat memberikan keuntungan antara dua belah pihak yaitu masyarakat sebagai penyetor dan bank sampah sebagai pengumpul sampah. Alur dari aplikasi ini sendiri akan tergambar pada gambar 1.

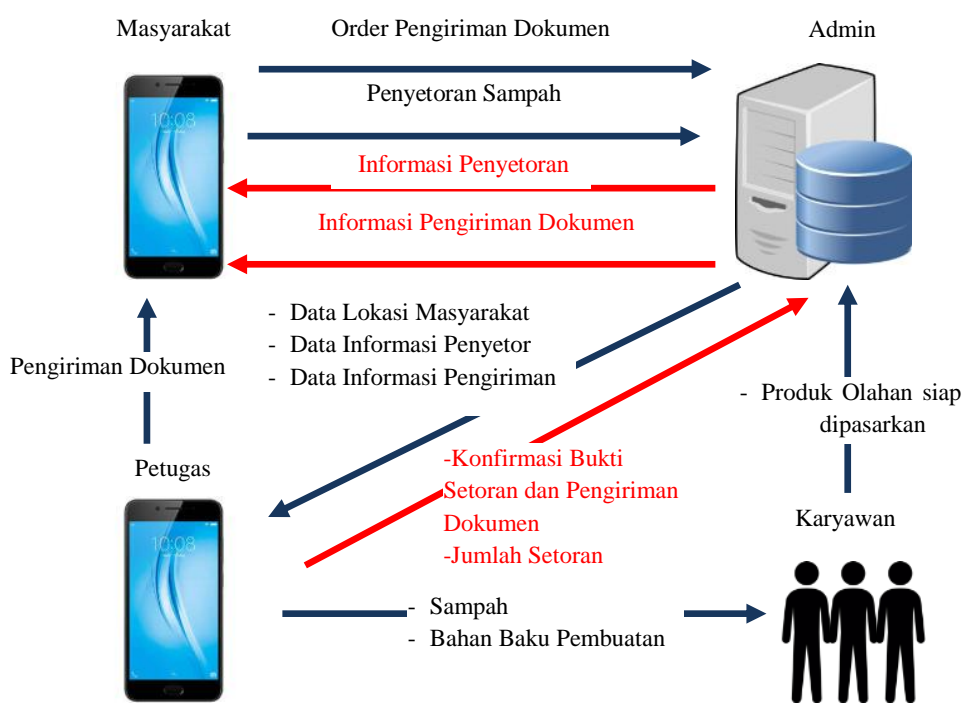

Gambar 1. Alur Sistem Sangkuts

Sementara itu, penggambaran dari sistem dari aplikasi Sangkuts ini akan tergambar alur prosesnya melalui usecase diagram. Use Case Diagram menampilkan aktor mana yang menggunakan Use Case mana, Use Case mana yang memasukkan use case lain dan hubungan antara aktor dan Use Case[5]. Berdasarkan alur dan kebutuhan system yang didapatkan data setelah melakukan observasi dan pengamatan pada system didalam bank sampah. Penggambaran perancangan Use Case aplikasi Sangkuts akan ditampilkan pada gambar 2 .

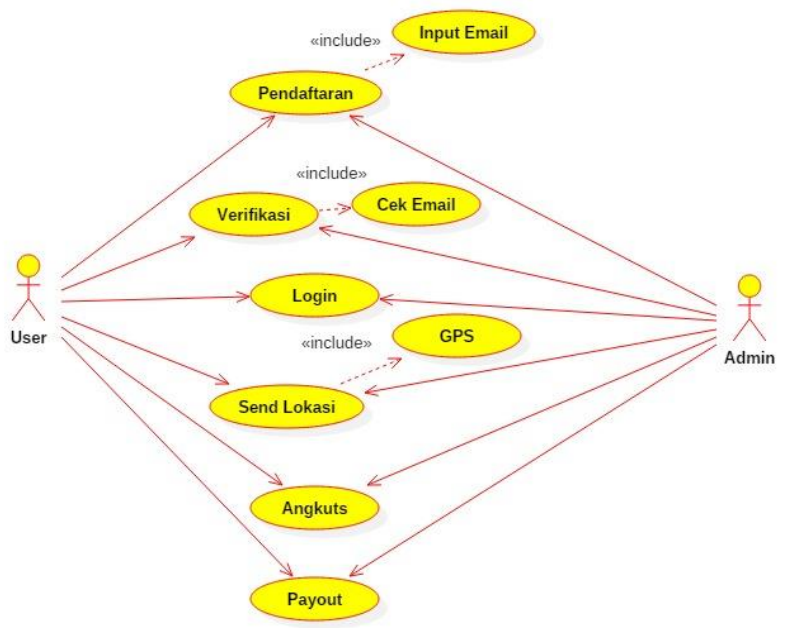

Gambar 2. Usecase Diagram Sistem

Pada Gambar 3 dibawah ini menunjukkan diagram aktifitas dari aktor masyarakat saat melakukan aktifitas pendaftaran aplikasi untuk jasa pengangkutan sampah, system dari Sangkuts sendiri akan dilakukan oleh petugas dari bank sampah. Diagram Aktifitas adalah tampilan grafis yang menjelaskan proses operasional dan hubungan sebab akibat yang digunakan di dalam setiap tahapan sistem [6]. Alur system dalam desain activity diagram akan ditunjukkan pada gambar 3. 


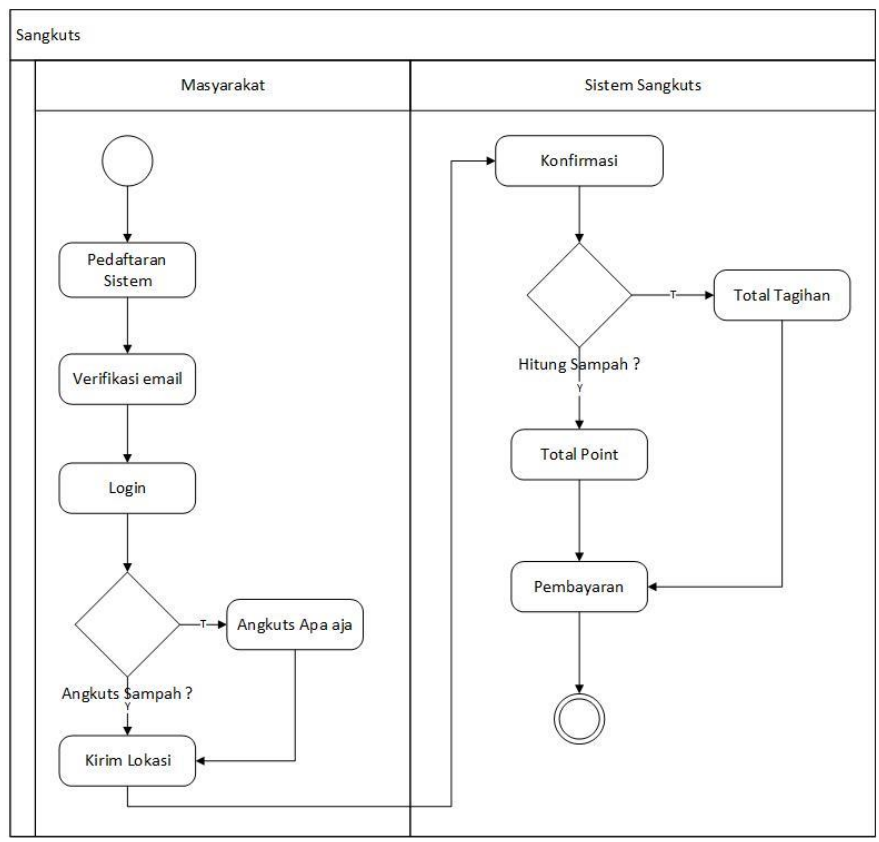

Gambar 3. Activity Diagram Sistem Sangkuts

Hasil tampilan antarmuka dari sistem apikasi sangkuts tengang jasa pengangkutan sampah di kabupaten Kudus ditunjukkan sebagai berikut. Gambar 4 ini menunjukkan tampilan login dari aplikasi Sangkuts. Dalam login aplikasi terlebih dahulu mendaftarkan diri, jika sudah memiliki akun maka pengguna dapat login sistem. Berikut adalah tampilan Login system dalam aplikasi yang terlihat pada gambar 4

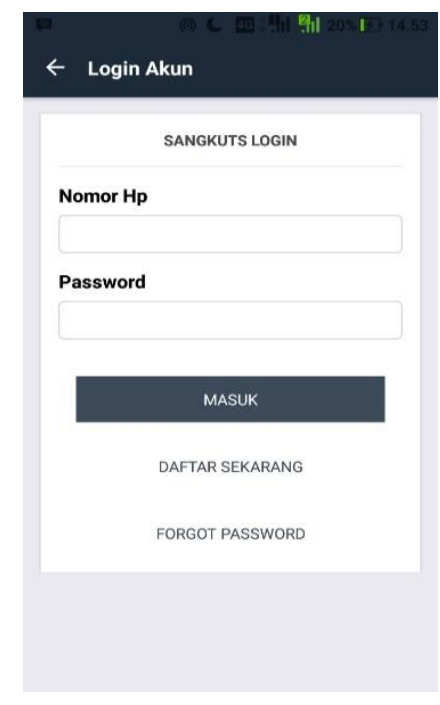

\section{Gambar 4. Desain Login Aplikasi Sangkuts}

Dalam gambar 5 menunjukkan fitur tampilan utama pemilihan jasa pengangkutan sampah atau pengangkutan apa saja berupa dokumen dan lain sebagainya dengan memanfaatkan teknologi GIS (Geographic Information System). Berikut adalah tampilan menu beranda dalam aplikasi yang terlihat pada gambar 5 .

Pada gambar 6 menunjukkan tampilan kategori sampah yang telah diolah dan dibuat untuk dijadikan barang yang mempunyai kratifitas dan dapat dijual kembali. Pengolahan sampah itupun dikelompokkan sesuai sampah yang diperoleh dan sesuai barang yang akan dibuat. Berikut adalah tampilan Pemasaran dalam aplikasi yang terlihat pada gambar 6 . 


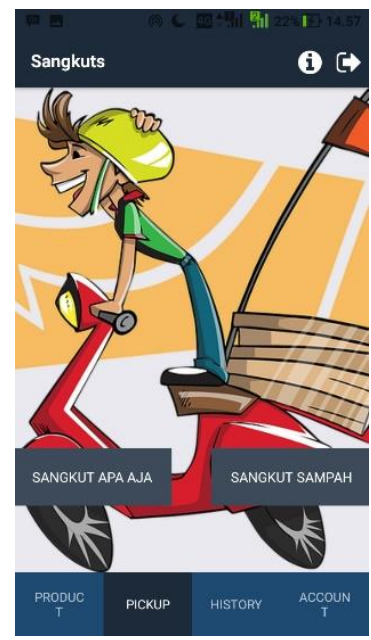

Gambar 5. Desain Tampilan Pickup Sangkuts

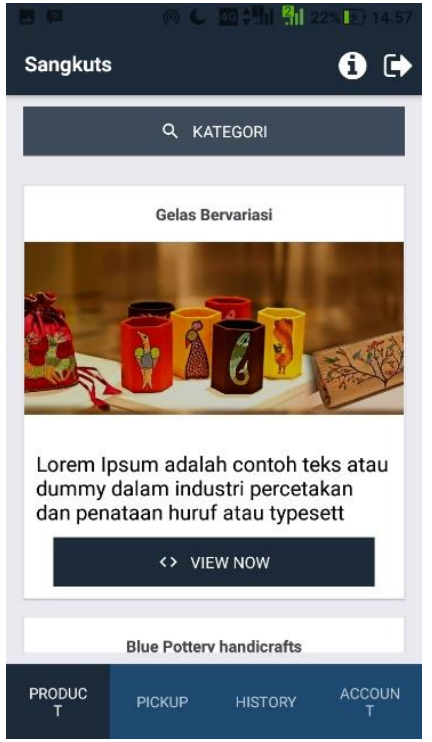

Gambar 6. Desain Tampilan Product Sangkuts

Pada gambar 7 menunjukkan tampilan history untuk penampilan setelah melakukan transaksi apa saja dalam apikasi sangkuts. Fitur ini di diperuntukkan didalam apikasi user atau pengguna jasa pengangkutan sampah atau disebut Sangkuts. Berikut adalah tampilan History dalam aplikasi yang terlihat pada gambar 7 .

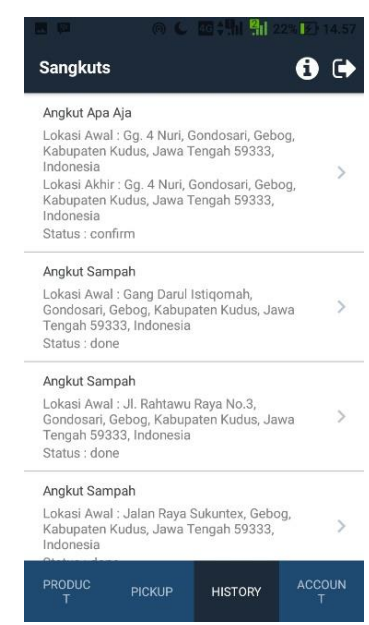

Gambar 7. Desain Tampilan History Sangkuts 
Pada gambar 8 menunjukkan tampilan profil dari user atau pengguna yang menggunakan aplikasi Sangkuts. Didalam tampilan ini dapat melihat point dari user dalam penyetoraan sampah dan user dapat payout uang point dan digantikan dengan sejumlah uang. Berikut adalah tampilan Account user dalam aplikasi yang terlihat pada gambar 8 .

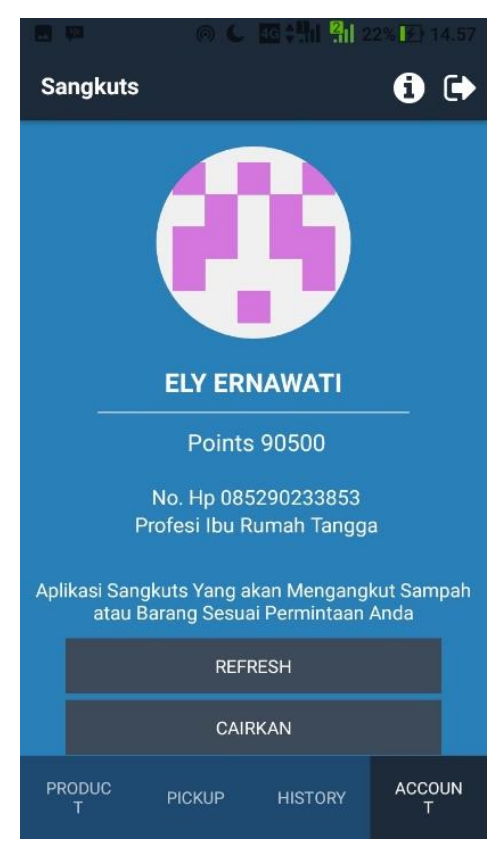

Gambar 8. Desain Tampilan Account Sangkuts

\section{KESIMPULAN}

Aplikasi untuk pengangkutan sampah ini bekerja dengan mempermudah petugas bank sampah dalam pendataan penyetor sampah dan memudahkan penyetor untuk menyetorkan sampah dengan tidak perlu datang ke bank sampah. Diharapkan dengan adanya aplikasi tersebut sehingga kinerja bank sampah dapat optimal dan masyarakat dapat lebih sering menyetorkan sampahnya ke bank sampah sehingga pada jangka panjang akan mengurangi jumlah sampah di masyarakat.

\section{UCAPAN TERIMA KASIH}

Terima kasih kepada Kementerian Riset, Teknologi, dan Pendidikan Tinggi Republik Indonesia yang telah membiayai penelitian ini melalui program kompetisi bisnis mahasiswa indonesia.

\section{DAFTAR PUSTAKA}

[1] Wahyuni, Tri.2016. Indonesia Penyumbang Sampah Plastik Terbesar Ke-dua Dunia.Jakarta: CNN Indonesia.(23 Februari 2016)

[2] Abidin, H. (2007). Penentuan Posisi dengan GPS dan Aplikasinya. Jakarta: PT. Pradnya Pramita.

[3] Tiwari, Vinay. 2010. "Some Observations On Open Source Software Development On Software Engineering Perspectives". International Journal of Computer Science \& Information Technology (IJCSIT) 2. 6, 113-125.

[4] Lee, Sunguk. 2012. "Unified Modeling Language (UML) for Database Systems and Computer Applications". International Journal of Database Theory and Application 5. 1, 157-164.

[5] Fowler, Martin. 2005. UML Distilled Edisi 3, Yogyakarta: Andi.

[6] Mallick, Bipsha., and Das, Nilanjan. 2013. "An Approach to Extended Class Diagram Model of UML for Object Oriented Software Design”. International Journal of Innovative Technology \& Adaptive Management (IJITAM) 1. 2. 